\title{
EFFECT OF COPPER GLYCINATE CHELATE ON BIOMECHANICAL, MORPHOMETRIC AND CHEMICAL PROPERTIES OF CHICKEN FEMUR*
}

\author{
Małgorzata Kwiecieńn ${ }^{1 \star}$, Anna Winiarska-Mieczan ${ }^{1}$, Kazimierz Zawiślak², Szymon Sroka1 \\ ${ }^{1}$ Institute of Animal Nutrition and Bromatology, University of Life Sciences, Akademicka 13, \\ 20-950 Lublin, Poland \\ ${ }^{2}$ Department of Food Engineering and Machinery, University of Life Sciences, Doświadczalna 44, \\ 20-280 Lublin, Poland \\ •Corresponding author: malgorzatakwiecienar@wp.pl
}

\begin{abstract}
The effect of $\mathrm{Cu}$ in the form of glycinate chelate, added to chicken feed mixtures, on biomechanical, morphometric and chemical parameters of chicken femur bones was evaluated at 6 weeks of age. Three hundred one-day-old Ross 308 male chicks were divided into 6 groups each in 5 repetitions of 10 chicks. The basal feed mixtures contained: starter $6.1 \mathrm{mg} \cdot \mathrm{kg}^{-1} \mathrm{Cu}$, grower $6.21 \mathrm{mg} \cdot \mathrm{kg}^{-1} \mathrm{Cu}$, finisher $5.91 \mathrm{mg} \cdot \mathrm{kg}^{-1} \mathrm{Cu}$. In the experiment $8,4 \mathrm{or} 2 \mathrm{mg} \cdot \mathrm{kg}^{-1}$ of copper were added to the premix (containing no $\mathrm{Cu}$ ) in the form of copper sulfate ( $\mathrm{S}-\mathrm{Cu}$ ) or as copper glycinate chelate (Gly-Cu). The highest cortical index and maximum elastic strength towards bone weight were observed when $\mathrm{S}-\mathrm{Cu}$ was added to the mixture at $25 \%$ of the requirement. Higher values of the maximum elastic strength were recorded in groups receiving $100 \%$ and $50 \% \mathrm{Gly}-\mathrm{Cu}$ compared to the group fed with $\mathbf{1 0 0} \%$ and $\mathbf{2 5 \%} \mathrm{S}-\mathrm{Cu}$. In chickens receiving Gly-Cu significantly higher Ix values were recorded in comparison with the group receiving $50 \% \mathrm{~S}-\mathrm{Cu}$. As an alternative to iron sulfate Ross 308 broiler chickens can be fed with $\mathrm{Fe}$ in the form of copper glycinate chelate. The use of chelate in the amount limited to $10 \mathrm{or} 20 \mathrm{mg} \cdot \mathrm{kg}^{-1}$ did not result in worse physicochemical, strength and morphometric parameters of chicken femurs compared to the recommended dose $\left(40 \mathrm{mg} \cdot \mathrm{kg}^{-1}\right)$.
\end{abstract}

Key words: chicken, glycinate chelate, bone parameters

Because microelements play a significant role in the correct development of bones, in particular in fast growing chickens (Julian, 2005), the assimilability of such elements can affect the growth and strength of bones (Dibner et al., 2007; OviedoRondón et al., 2006). From the point of view of poultry feeding practice, the process of mineralization of bone tissue, including leg bones, is a very important indicator of the effectiveness and quality of feeding procedures and an indicator of the organism's health status (Crespo et al., 2000).

\footnotetext{
*This work was supported from funds of the Ministry of Agriculture and Rural Development, project No. N N311 543540.
} 
Precise balancing of macro- and microelements and improvement of their absorption in various combinations allows considerably reducing the emission of mineral compounds unused by birds. Therefore, chemical compounds whose availability in the alimentary tract is increased are more and more often used, which enables their better use. The tests point to the beneficial effects of using organic forms of microelements on the results of chicken rearing, mostly with regard to their better assimilability (Chowdhury et al., 2004; Bao et al., 2007; Dobrzański et al., 2008; Nollet et al., 2008). Literature does not provide many results of experiments that associate the form of mineral components with bone quality. Increased content of crude ash in bones can be a good indicator of the degree of bone mineralization, depending on the availability of $\mathrm{P}, \mathrm{Ca}$ and other elements forming phytate complexes. Higher content of crude ash in chicken bones was found when the element was used in an organic form (Banks et al., 2004; Abdallah et al., 2009). In turn, Bao et al. (2007) and Wang et al. (2007) in chickens and Mikulski et al. (2009) in turkeys found no significant differences in ash content depending on the chemical form of $\mathrm{Cu}$. Also, Kwiecień et al. (2005) demonstrated that an addition of $\mathrm{Cu}$ and lysine bioplex made no significant difference in terms of crude ash content in the tibia of turkeys.

Recently, there has been increased interest in new generation chelates, i.e. glycinate chelates. Feed grade chelates based on glycine seem to be a good solution to supplement microelement deficiency in feed rations. Glycine, as a component of chelate, is the most easily assimilable amino acid, which, with its wide range of applications, additionally improves the values of this additive. Copper is one of the microelements used in combinations with amino acids. This element has a wide spectrum of action, which makes it a participant in many metabolic processes in the organism, and thus it can have a material impact on the health status of animals (Rinaldi, 2000). Copper deficiency contributes to increased permeability and reduced strength of collagen, which can be a reason for many disorders in the organism. As a consequence of defective networks of collagen polypeptide chains in the osseous system the shaft of the bone is weakened, resulting in development disorders, fractures and numerous deformations. The underlying reason for changes in the osseous system in the case of copper deficiency involves functional defects of osteoblasts (bone tissue forming cells), while the activity of osteoclasts (bone tissue removing cells) remains unchanged (Gahrke, 1997). According to the Polish Feeding Standards for Poultry (2005), chicks' requirement of copper is $7-8 \mathrm{mg} \cdot \mathrm{kg}^{-1}$, and the company Ross (Aviagen, 2013) recommends $16 \mathrm{mg} \cdot \mathrm{kg}^{-1} \mathrm{Cu}$. However, the use of $\mathrm{Cu}$ from natural feeds is limited and results from the risk of precipitation or complexing of metal cations by fractions of fibre, phytin and other compounds in the alimentary tract environment, which can cause a double deficit of this element in the organism (Leeson, 2005). In order to avoid the consequences of this mineral deficiency, its content in feed is increased. With regard to the important role of $\mathrm{Cu}$ in the development of bones, it is hypothesized that the use of $\mathrm{Cu}$ in a more assimilable form can improve the development of the osseous system in the early stages of the birds' life and reduce leg problems in the future (Fuchs et al., 2008, 2009). Studies by Kwiecień (2012) show that the use of $\mathrm{Cu}$ in the form of glycinate compounds at the level of $2 \mathrm{mg} \cdot \mathrm{kg}^{-1}$ instead of $\mathrm{Cu}$ added in the form of sulfate according to recommended dos- 
age did not cause a deterioration in the physical, chemical, mechanical and morphometric properties of the femoral bone. However, the number of scientific analyses involving the use of glycinate chelates in feeding of broiler chickens and their effect on the bone structure forming processes is limited; therefore, this work focuses on these issues. The objective of this study was to compare the effect of two chemical forms (sulfates and glycinate chelates) of copper administered in various amounts in feed mixtures for Ross 308 broiler chickens on the biomechanical, morphometric and chemical properties of chicken femur.

\section{Material and methods}

\section{Experimental design}

All procedures used during the study were approved by the Local Ethics Committee for Animal Testing at the University of Life Sciences in Lublin. Three hundred one-day-old Ross 308 chicks were split into 6 groups, each in 5 repetitions of 10 chicks. The birds were weighed at the beginning of the experiment and on day 1 of rearing each bird was identified with a wing tag. Ross 308 male chicks were reared in cages in a controlled temperature and humidity environment. In the first week the chicks were kept at a temperature of $33^{\circ} \mathrm{C}$. Each week the temperature was reduced by $2{ }^{\circ} \mathrm{C}$ until finally $24^{\circ} \mathrm{C}$ was reached.

Basal diets for the birds were prepared on the basis of ground corn, wheat and extracted soya meal. The composition and calculated nutritive value of basal feed mixtures are presented in Table 1. The birds were fed ad libitum with diets appropriate for respective growth periods, i.e. starter $-\mathrm{S}$ (days 1-21), grower - G (days 22-35) and finisher - F (days 36-42), and had unlimited access to water. Starter diets were administered to chicks in crumbled form and grower and finisher diets as pellets. The diets were supplemented with $\mathrm{Cu}$ in inorganic form (sulfate) and organic form (glycinate chelate), covering $100 \%, 50 \%$ or $25 \%$ of the total requirement of the component recommended for Ross 308 broiler chicks, i.e. $16 \mathrm{mg} \cdot \mathrm{kg}^{-1}$ (Aviagen, 2013). The basal diets contained: starter $6.1 \mathrm{mg} \cdot \mathrm{kg}^{-1} \mathrm{Cu}$, grower $6.21 \mathrm{mg} \cdot \mathrm{kg}^{-1} \mathrm{Cu}$, finisher 5.91 $\mathrm{mg} \cdot \mathrm{kg}^{-1} \mathrm{Cu}$. In the experiment 16,8 or $4 \mathrm{mg} \cdot \mathrm{kg}^{-1}$ of copper were added to the premix (containing no $\mathrm{Cu}$ ) in groups I, II and III as copper sulfate $(\mathrm{S}-\mathrm{Cu})$, and in groups IV, $\mathrm{V}$ and VI as copper glycinate chelate (Gly-Cu). The experiment involved the use of Glystar Forte chelate (Arkop, Poland) containing 16\% of $\mathrm{Cu}$.

\section{Biomechanical, morphometric and chemical properties of femur}

On the last day of rearing, the birds were weighed and 10 from each group with body weight closest to the average weight in the group were selected for dissection. After $10 \mathrm{~h}$ starvation the birds were slaughtered (Council Regulation (EC) No. 1099/2009 of 24 September 2009) and their right leg femoral bones were prepared. Bone samples were mechanically cleared of soft tissue and their length was measured with an electronic slide caliper (accurate to $0.001 \mathrm{~mm}$ ), each time in an identical measuring position. Then, bone circumference was measured at one-half of bone 
length, and the samples were packed into labelled foil bags and frozen at $-25^{\circ} \mathrm{C}$ until analyses.

Table 1. Ingredients of basal diet and nutritional value ( $\%$, as fed basis)

\begin{tabular}{|c|c|c|c|}
\hline Ingredients $(\%)$ & $\begin{array}{c}\mathrm{S} \\
(1-21 \text { days })^{1}\end{array}$ & $\begin{array}{c}\mathrm{G} \\
(22-35 \text { days })^{2}\end{array}$ & $\begin{array}{c}\mathrm{F} \\
(36-42 \text { days })^{3}\end{array}$ \\
\hline Maize & 24.44 & 40.00 & 40.00 \\
\hline Wheat & 42.99 & 27.84 & 28.84 \\
\hline Soybean meal* & 25.0 & 24.97 & 22.87 \\
\hline Soybean oil & 2.50 & 3.69 & 3.98 \\
\hline Monocalcium phosphate & 0.90 & 0.90 & 0.81 \\
\hline Limestone & 1.40 & 1.13 & 1.09 \\
\hline Sodium bicarbonate & 0.08 & 0.08 & 0.08 \\
\hline $\mathrm{NaCl}$ & 0.29 & 0.25 & 0.26 \\
\hline Vitamin-mineral premix (without $\mathrm{Cu}$ ) & $0.50 \mathrm{a}$ & $0.50 \mathrm{~b}$ & $0.50 \mathrm{c}$ \\
\hline Fat-protein concentrate $* *$ & 1.00 & - & 1.00 \\
\hline DL-methionine $99 \%$ & 0.30 & 0.23 & 0.23 \\
\hline L-lysine $\mathrm{HCl}$ & 0.42 & 0.28 & 0.27 \\
\hline L-threonine $99 \%$ & 0.18 & 0.13 & 0.07 \\
\hline \multicolumn{4}{|l|}{$1 \mathrm{~kg}$ feed mixture contains: } \\
\hline${ }^{\mathrm{e}}$ metabolizable energy $\left(\mathrm{ME}, \mathrm{MJ} \mathrm{kg}^{-1}\right)$ & 12.7 & 13.1 & 13.2 \\
\hline${ }^{\mathrm{d}}$ crude protein $(\%)$ & 20.2 & 18.2 & 18.1 \\
\hline${ }^{\mathrm{d}}$ crude fibre $(\%)$ & 3.06 & 2.99 & 2.99 \\
\hline${ }^{\mathrm{d}}$ crude fat $(\%)$ & 4.66 & 6.08 & 6.43 \\
\hline${ }^{\mathrm{d}}$ Lysine (\%) & 1.29 & 1.13 & 1.09 \\
\hline${ }^{\mathrm{d}}$ Met + Cys $(\%)$ & 0.93 & 0.83 & 0.81 \\
\hline${ }^{\mathrm{d}}$ total $\mathrm{Ca}(\%)$ & 0.88 & 0.78 & 0.75 \\
\hline d total P (\%) & 0.66 & 0.65 & 0.63 \\
\hline eavailable P (\%) & 0.42 & 0.41 & 0.39 \\
\hline etotal Ca/available $\mathrm{P}$ & 2.12 & 1.90 & 1.92 \\
\hline \multicolumn{4}{|l|}{${ }^{\mathrm{d}} \mathrm{Cu}(\mathrm{mg})$} \\
\hline $16 \mathrm{mg} \mathrm{S}-\mathrm{Cu}$ & 22.10 & 22.21 & 21.95 \\
\hline $8 \mathrm{mg} \mathrm{S}-\mathrm{Cu}$ & 13.98 & 14.02 & 13.89 \\
\hline $4 \mathrm{mg} \mathrm{S}-\mathrm{Cu}$ & 10.21 & 10.11 & 9.91 \\
\hline 16 mg Gly.-Cu & 21.98 & 22.15 & 22.02 \\
\hline $8 \mathrm{mg}$ Gly.-Cu & 14.12 & 14.21 & 14.01 \\
\hline 4 mg Gly.-Cu & 10.10 & 10.21 & 9.98 \\
\hline${ }^{\mathrm{d}} \mathrm{Fe}(\mathrm{mg})$ & 40.31 & 39.82 & 38.61 \\
\hline${ }^{\mathrm{d}} \mathrm{Zn}(\mathrm{mg})$ & 99.71 & 98.50 & 98.52 \\
\hline
\end{tabular}

a - composition of the premix per kg of starter diet: Mn $100 \mathrm{mg}$, I $1 \mathrm{mg}, \mathrm{Fe} 40 \mathrm{mg}$, Zn $100 \mathrm{mg}$, Se $0.15 \mathrm{mg}$, vit. A $15000 \mathrm{IU}$, vit. $\mathrm{D}_{3} 5000 \mathrm{UI}$, vit. E $75 \mathrm{mg}$, vit. $\mathrm{K}_{3} 4 \mathrm{mg}$, vit. $\mathrm{B}_{1} 3 \mathrm{mg}$, vit. $\mathrm{B}_{2} 8 \mathrm{mg}$, vit. $\mathrm{B}_{6} 5 \mathrm{mg}$, vit. $\mathrm{B}_{12} 0.016$ $\mathrm{mg}$, biotin $0.2 \mathrm{mg}$, folic acid $2 \mathrm{mg}$, nicotic acid $60 \mathrm{mg}$, pantothenic acid $18 \mathrm{mg}$, choline $1800 \mathrm{mg}$;

$\mathrm{b}$ - composition of the premix per $\mathrm{kg}$ of grower diet: Mn $100 \mathrm{mg}, \mathrm{I} 1 \mathrm{mg}, \mathrm{Fe} 40 \mathrm{mg}$, Zn $100 \mathrm{mg}$, Se $0.15 \mathrm{mg}$, vit. A $12000 \mathrm{IU}$, vit. $\mathrm{D}_{3} 5000 \mathrm{UI}$, vit. E $50 \mathrm{mg}$, vit. $\mathrm{K}_{3} 3 \mathrm{mg}$, vit. $\mathrm{B}_{1} 2 \mathrm{mg}$, vit. $\mathrm{B}_{2} 6 \mathrm{mg}$, vit. $\mathrm{B}_{6} 4 \mathrm{mg}$, vit. $\mathrm{B}_{12} 0.016$ $\mu \mathrm{g}$, biotin $0.2 \mathrm{mg}$, folic acid $1.75 \mathrm{mg}$, nicotic acid $60 \mathrm{mg}$, pantothenic acid $18 \mathrm{mg}$, choline $1600 \mathrm{mg}$;

$\mathrm{c}$ - composition of the premix per kg of finisher diet: Mn $100 \mathrm{mg}$, I $1 \mathrm{mg}, \mathrm{Fe} 40 \mathrm{mg}$, Zn $100 \mathrm{mg}$, Se $0.15 \mathrm{mg}$, vit. A $12000 \mathrm{IU}$, vit. $\mathrm{D}_{3} 5000$ j.m., vit. E $50 \mathrm{mg}$, vit. $\mathrm{K}_{3} 2 \mathrm{mg}$, vit. $\mathrm{B}_{1} 2 \mathrm{mg}$, vit. $\mathrm{B}_{2} 5 \mathrm{mg}$, vit. $\mathrm{B}_{6} 3 \mathrm{mg}$, vit. $\mathrm{B}_{12} 0.011$ $\mu \mathrm{g}$, biotin $0.05 \mathrm{mg}$, folic acid $1.5 \mathrm{mg}$, nicotic acid $35 \mathrm{mg}$, pantothenic acid $18 \mathrm{mg}$, choline $1600 \mathrm{mg}$.

${ }^{\mathrm{d}}$ values analysed; ${ }^{\mathrm{e}}$ values calculated.

* $-46 \%$ crude protein in the dry matter.

** $-1 \mathrm{~kg}$ of protein-fat concentrate contained: $2 \%$ crude fat, $39 \%$ crude protein, $10.8 \mathrm{MJ} \mathrm{ME}$.

${ }^{1} \mathrm{~S}$ - starter mixture (1-21 days).

${ }^{2} \mathrm{G}$ - grower mixture (22-35 days).

${ }^{3} \mathrm{~F}$ - finisher mixture (36-42 days). 
Mechanical properties of the bones were determined identically for both groups after thawing at room temperature using a three-point bending test in an INSTRON 4302 apparatus (Instron, Canton, USA) linked with a computer. The relationship between forces perpendicular to the longitudinal axis of the bone and the displacement were registered. The distance between bone supports was set at $40 \%$ of the total bone length and bone samples were loaded with a constant speed of $10 \mathrm{~mm} / \mathrm{min}$. The maximum elastic strength (Wy) and the ultimate strength (Wf) of the bones were determined (Ferretti et al., 1993 a). In addition, Young's modulus was calculated according to the formula:

$$
E=\frac{W y \cdot L}{12 d y \pi I x}
$$

where:

$E$ - Young's modulus,

$L$ - spacing of supports in bending test,

$d y$ - yielding deformation,

$I x$ - second moment of inertia,

and bone density index was determined (Bruno et al., 2007):

$$
B D I=b w / b l
$$

where:

$B D I$ - bone density index,

$b w$ - bone weight,

$b l$ - bone length.

Geometric and cortical properties of the bones were estimated on the basis of measuring the horizontal and vertical diameters of the mid-diaphyseal cross-section of bone. The cross-section area (A), the second moment of interia (Ix), and the mean relative wall thickness (MRWT) were determined using the following formulas:

$$
I x=3.14\left(V^{3} H-v^{3} h\right) / 64, A=3.14(H V-h v) / 4, M R W T=[(V-v) / v+(H-h) / h] / 2
$$

The cortical layer thickness (CLT), the cortical index (CI), the cortical surface (CS) and the cortical surface index (CSI) were determined using the following formulas:

$$
\mathrm{C} L T=H-h ; C I=(H-h / H) \times 100 ; C S=H^{2}-h^{2} ; C S I=\left(H^{2}-h^{2} / H^{2}\right) \times 100
$$

where:

$H$ - horizontal external diameter of the cross-section of the bone,

$h$ - horizontal internal diameter of the cross-section of the bone,

$V$ - vertical external diameter of the cross-section of the bone,

$v$ - vertical internal diameter of the cross-section of the bone (Ferretti et al., $1993 \mathrm{a}, \mathrm{b})$. 
After evaluating the strength and structural properties, the femurs were defatted, dried to constant mass and finally mineralized in a muffle furnace at $600^{\circ} \mathrm{C}$ (AOAC, 2000). The content of mineral components ( $\mathrm{Ca}, \mathrm{Mg}, \mathrm{Cu}, \mathrm{Fe}, \mathrm{Zn}$ ) in bones was determined by atomic absorption spectrometry using a Unicam 939/959 apparatus, and total P content (PN-76/R-64781) with a Helios $\alpha$-Unicam apparatus, using molybdenum and vanadium as the reagent $\left(\mathrm{NH}_{4} \mathrm{VO}_{3},\left(\mathrm{NH}_{4}\right)_{6} \mathrm{Mo}_{7} \mathrm{O}_{24} \cdot \mathrm{H}_{2} \mathrm{O}, \mathrm{H}_{2} \mathrm{O}\right)$. The content of $\mathrm{Ca}, \mathrm{Mg}, \mathrm{Cu}, \mathrm{Fe}$ and $\mathrm{Zn}$ in the bone was calculated as the content of these components in crude ash.

\section{Analysis of the feed}

The content of dry matter, total protein, fat and crude fibre was determined in the feed mixtures according to AOAC (2000) and mineral component levels were measured by methods described above as used in bone analyses. The amino acid composition was determined by ion-exchange chromatography using an INGOS AAA 400 amino acid analyser with post-column derivatization of ninhydrine and spectrophotometric detection according to the standard manufacturer's procedure and MCMiAŻ/PB-03 test procedure. The samples were hydrolyzed in aqueous solution $\left(6 \mathrm{~N} \mathrm{HCl}+0.5 \%\right.$ phenol at $110^{\circ} \mathrm{C}$ for 24 hours). Sulfur amino acids (cysteine and methionine) were determined in a separate analysis as oxidized derivatives (cysteic acid and methionine sulfone) resulting from oxidation with performic acid and then released from proteins during acid hydrolysis. Following this reaction, the tested samples were again subjected to acid hydrolysis (Arnoldi, 2001; Žilic et al., 2006).

\section{Statistical analyses}

The results were statistically verified by two-way analysis of variance using General Linear Model (GLM) ANOVAs combined with Duncan's multiple range tests (SAS statistical software, version 9.1.3; SAS Institute Inc., Cary, NC). The model considered the constant impact of the level, sources and level-source interactions. Differences showing $\mathrm{P} \leq 0.01$ were considered as statistically significant.

\section{Results}

At 6 weeks of age the lowest body weight ( $2324 \mathrm{~g})$ was recorded in the group of chicks fed on a mixture with a level of $\mathrm{Cu}$ reduced to $50 \%$ in the form of $\mathrm{S}-\mathrm{Cu}$, and the highest weight ( $2485 \mathrm{~g}$ ) was noted in the group receiving a mixture with $\mathrm{Gly}-\mathrm{Cu}$ covering $100 \%$ of the requirement (Table 2). No influence of the form of $\mathrm{Cu}$ level on the consumption of feed by the chicks was found throughout the rearing period. On day 42 of life, higher bone weight $(\mathrm{P} \leq 0.01)$ per $100 \mathrm{~g}$ of body weight, confirmed by statistical methods, was identified in chicks receiving additives: $25 \% \mathrm{Gly}-\mathrm{Cu}$ and $50 \% \mathrm{~S}-\mathrm{Cu}$ compared to chicks fed with the recommended dose of $\mathrm{S}-\mathrm{Cu}$ limited to $25 \%$ and to groups receiving Gly-Cu additive covering $100 \%$ and $50 \%$ of the copper requirement (Table 2). 


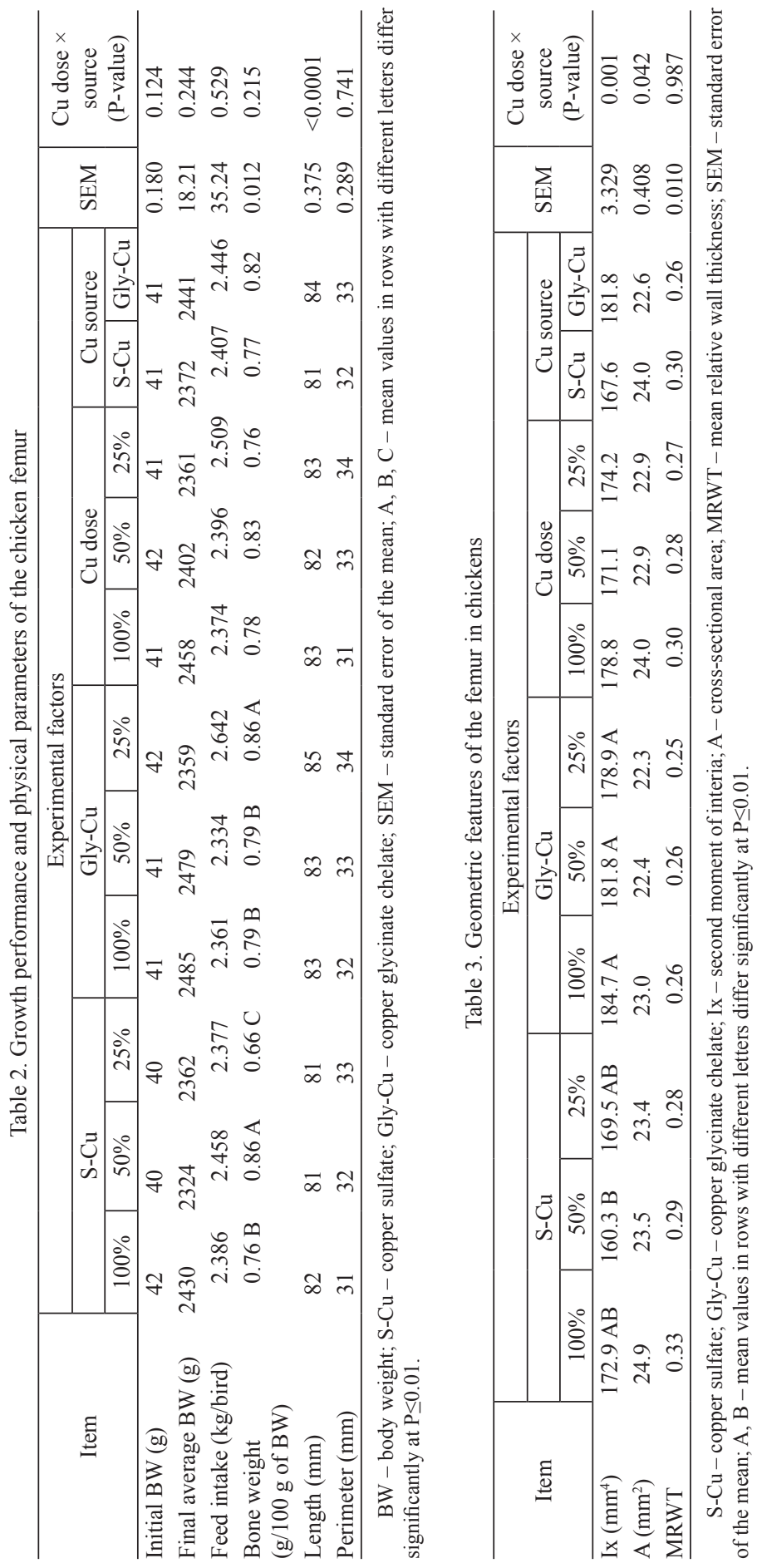




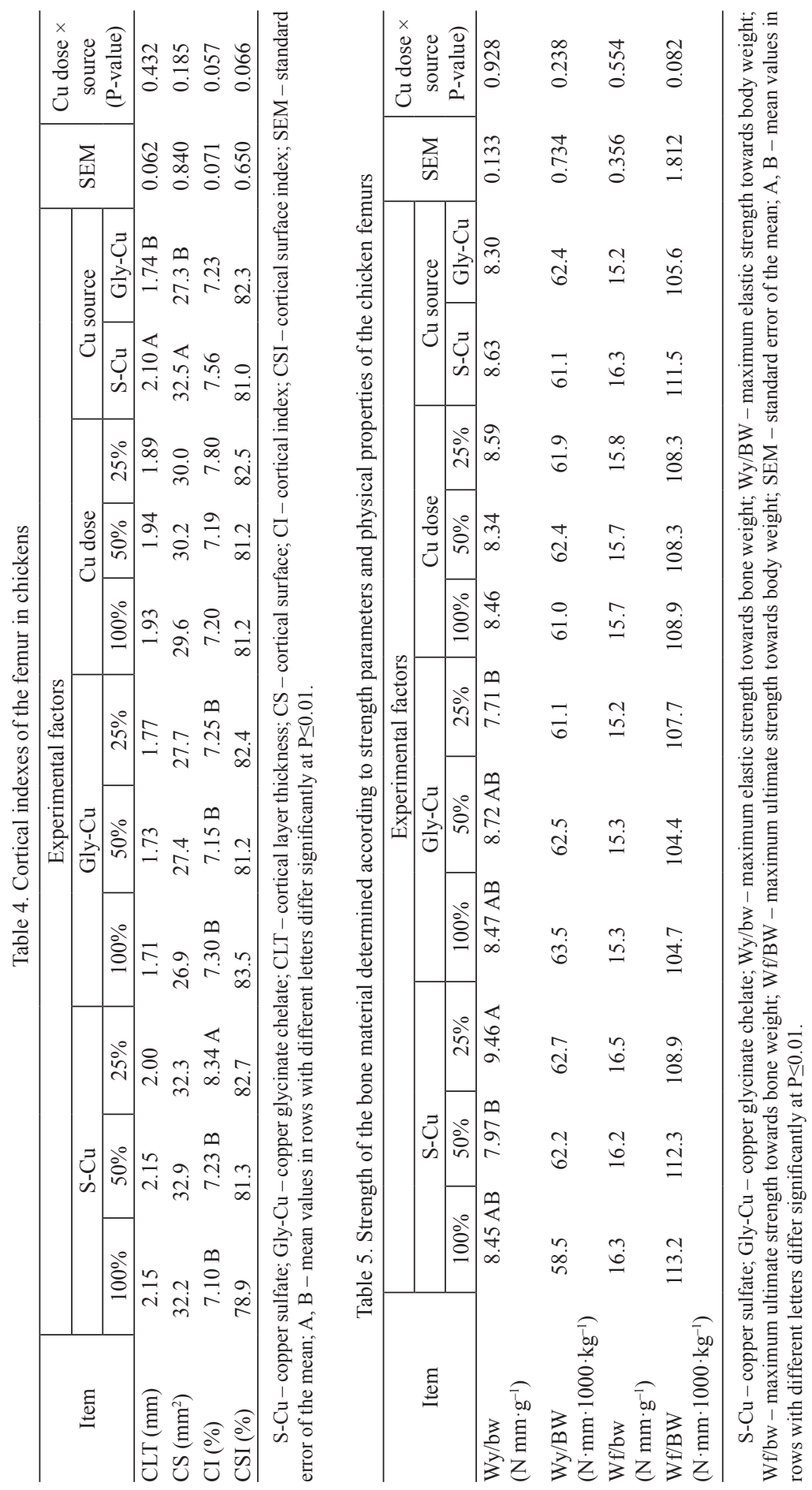




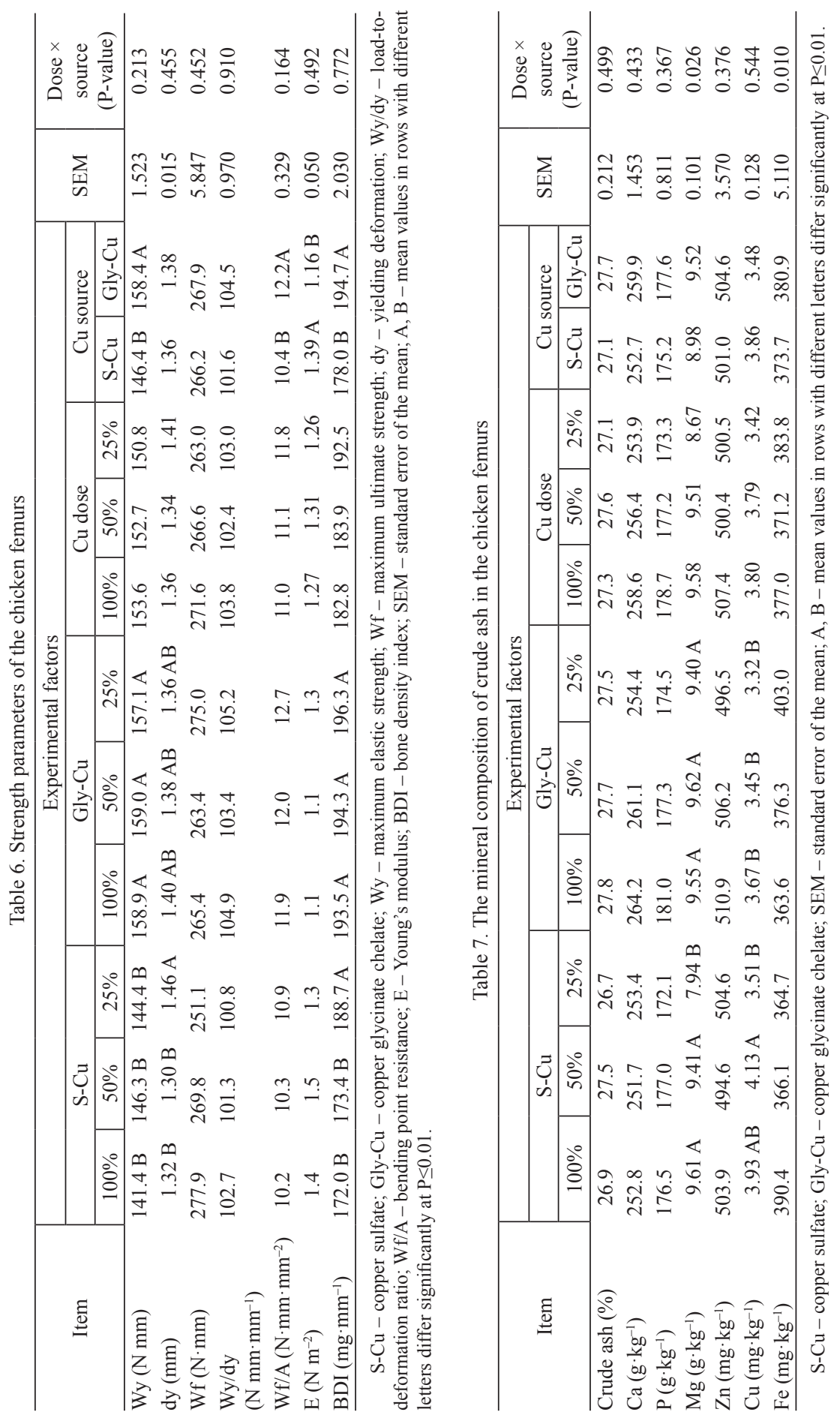


In chickens receiving Gly-Cu significantly higher Ix values were recorded in comparison with the group receiving $50 \% \mathrm{~S}-\mathrm{Cu}$ (Table 3). Interaction was identified $(\mathrm{P} \leq 0.001)$ between the source and the level of $\mathrm{Cu}$ in the value of Ix parameter.

The highest cortical index and maximum elastic strength towards bone weight were observed when $\mathrm{S}-\mathrm{Cu}$ was added to the mixture at $25 \%$ of the requirement (Tables 4 and 5).

Regardless of the level of Gly-Cu additive significantly higher values of the maximum elastic strength were recorded in comparison with those in groups receiving $\mathrm{Cu}$ as sulfate (Table 6). The $\mathrm{S}-\mathrm{Cu}$ additive limited to $25 \%$ of the requirement contributed to a significant $(\mathrm{P} \leq 0.01)$ increase in the dy value of chicken femurs compared to the group receiving additive $\mathrm{S}-\mathrm{Cu}$ covering $100 \%$ and $50 \%$ of the requirement. The effect of the chemical form of $\mathrm{Cu}$ on bending point resistance, Young's modulus and BDI was demonstrated. Increased values of the studied parameters, except for Young's modulus, were found for $\mathrm{Cu}$ additive in an organic form. The addition of $\mathrm{S}-\mathrm{Cu}$ at the recommended level and at $50 \%$ reduced $(\mathrm{P} \leq 0.01)$ bone density index values compared to those recorded in chicks receiving Gly-Cu at the level covering 100,50 and $25 \%$ of the requirement and $\mathrm{S}-\mathrm{Cu}$ at $25 \%$ (Table 6 ).

On day 42 of age the lowest concentration of $\mathrm{Mg}$ was characteristic of the bones of birds receiving $\mathrm{Cu}$ additive in an inorganic form covering $25 \%$ of the requirement, while the highest content of $\mathrm{Cu}$ in the femur of chicks $(\mathrm{P} \leq 0.01)$ was identified when $\mathrm{S}-\mathrm{Cu}$ was added at 50\% (Table 7).

\section{Discussion}

The addition of $\mathrm{Cu}$ covering one-half or one-fourth of the chicks' copper requirement, in the form of sulfate and chelate respectively, contributed to a significant increase in bone weight per $100 \mathrm{~g}$ of body weight. After 42 days of growth the highest $\mathrm{Wy} / \mathrm{bw}$ ratio determining the strength of bone material $(\mathrm{P} \leq 0.01)$ was recorded when $\mathrm{S}-\mathrm{Cu}$ feed additive was reduced to $25 \%$, compared to chicks fed on $\mathrm{S}-\mathrm{Cu}$ at $50 \%$ and Gly-Cu at $25 \%$ of the requirement of this element. The use of Gly-Cu in an amount covering $25 \%$ of the requirement of this element did not result in significant changes in bone mineralization, which is shown by the lack of significant differences in bone length and circumference and lack of negative changes in bone strength parameters.

The results of studies into the effects of using various forms of $\mathrm{Cu}$ on the quality of bones in broiler chickens are scarce. A study by Kwiecien (2012) found that the bones were the heaviest, longest and had the largest circumference when $\mathrm{Cu}$ was added at $25 \%$ of the requirement. Similarly, the results of bone mineralization tests carried out by Banks et al. (2004) showed that the tibias of chicks receiving $\mathrm{Cu}-$ lysine were the heaviest compared with birds administered copper citrate or sulfate additives. In turn, Kwiecień et al. (2005) argue that an addition of Cu-lysine bioplex contributed to a reduction of bone weight, both in the case of fresh (by 14.1\%) and air-dried bones $(8 \%)$. 
Among the factors affecting the strength of bone tissue are structural properties of bones resulting from the spatial arrangement of the bone material and its microarchitecture. The value of the indicators of morphometric parameters of femoral bones in respective groups was similar, which indicates that the levels of organic and inorganic sources used had no significant effect on the analysed characteristics of chicken bones. Only in the case of Ix at the dose of 50\% S-Cu was this bone characteristic seen to decrease $(\mathrm{P} \leq 0.01)$ compared to its value recorded for groups receiving Gly$\mathrm{Cu}$, regardless of its level. Also in the study by Kwiecien (2012) the substitution of inorganic $\mathrm{Cu}$ with an identical amount of its organic equivalents had no significant effect on the morphometric parameters of chicken femur. Thus, it seems that $\mathrm{Cu}$ administered both in organic and inorganic form ensured the correct increase in volume and cross-sectional area without excessively increasing the weight of bone tissue, which is significant in flightless breeding birds. On the contrary, the study by Ferket et al. (2009) demonstrated that in turkeys fed with microelements (among other elements - chelated $\mathrm{Cu}$ ) the cortical bone area in the tibia was definitely thicker. In this study, the use of a $\mathrm{Cu}$ additive in organic form, regardless of the level, contributed to an increase in the maximum elastic strength of $11 \%$ compared to groups receiving $\mathrm{S}-\mathrm{Cu}$. One can suppose that diets supplemented with $\mathrm{Cu}$ in organic form may result in increased intestinal absorption of mineral components, which in turn increases the assimilability of $\mathrm{Ca}$ and $\mathrm{P}$ in birds and improves bone strength. A study by Kwiecien et al. (2005) demonstrated that $\mathrm{Cu}$-lysine chelate reduced the absolute strength of tibia in chickens by $20.5 \%$ compared to the bone strength in chicks from the control group without added chelate. In addition, the present study observed an increase in bone density index in groups receiving $\mathrm{Cu}$ chelate compared to groups receiving supplemental $\mathrm{Cu}$ in the form of sulfate, which can be explained by a increase in the weight of femoral bones. This is also evidence of a high degree of bone mineralization.

Crude ash content in the femur of chickens in the performed studies was not determined by the level and form of $\mathrm{Cu}$. In turn, Abdallah et al. (2009) found a significantly higher percentage of crude ash in the tibia of chickens whose diet contained $100 \%$ of peptide chelate compared to chicks receiving mineral components in inorganic forms. The results of Yan and Waldroup (2006) showed no significant differences in the content of ash in the bones of chickens depending on the source of the component. In the present study, the relationship between the content of mineral components and their form of administration was not confirmed by statistics every time; however, a higher concentration of the analysed components (except $\mathrm{Cu}-\mathrm{P} \leq 0.01$ ) was observed in groups in which an organic source of $\mathrm{Cu}$ was included in the diet. This may provide evidence for improved utilization of the feed components and increased bone mineral apposition. It also confirms the role of copper in the skeleton mineralization process. In turn, Mikulski et al. (2009) did not observe any changes in the physical and chemical properties of tibia in turkeys under the influence of inorganic and organic forms of $\mathrm{Cu}$. A study by Banks et al. (2004) showed that chicks receiving $\mathrm{Cu}$-lysine had the highest content of $\mathrm{Cu}$ in ash compared with birds administered copper citrate or sulfate additive. On the other hand, Wang et al. (2007) found that the high content of $\mathrm{Cu}$, resulting from $\mathrm{Cu}$ sulfate or organic form 
of $\mathrm{Cu}$ such as Mintrex ${ }^{\circledR}$ preparation added at $500 \mathrm{mg} \cdot \mathrm{kg}^{-1}$ significantly increased the concentration of $\mathrm{Cu}$ in bone ash in the case of both forms. In turn, Bao et al. (2007) reported that the content of $\mathrm{Cu}$ in the tibia was not materially determined by the amount of this component administered as chelate; thus, it is pointless to administer excessive amounts of it. Further $\mathrm{Cu}$ supplementation from inorganic and/or organic sources increases the $\mathrm{Cu}$-excretion and may cause additional environmental problems. Only in the case of $\mathrm{Zn}$ was it found that an increased supply of this element in organic form contributed to increased deposition of $\mathrm{Zn}$ in bones.

It can be summarized that Ross 308 broiler chickens can be fed with Fe in the form of copper glycinate chelate as an alternative to iron sulfate. The use of chelate in the amount limited to 10 or $20 \mathrm{mg} \cdot \mathrm{kg}^{-1}$ did not result in worse physicochemical, strength and morphometric parameters of chicken femurs compared to the recommended dose $\left(40 \mathrm{mg} \cdot \mathrm{kg}^{-1}\right)$.

\section{References}

A bdallah A.G., E 1-H u s s e in y O.M., A bde l- L at if K.O. (2009). Influence of some dietary organic mineral supplementations on broiler performance. Int. J. Poultry Sci., 8 (3): 291-298.

AOAC (2000). Official Methods of Analysis. Int. 17th ed. AOAC Inter., Gaithersburg, MD, USA.

A r nold i A. (2001). Thermal processing and food quality: analysis and control. Thermal Technologies in Food Processing. Ed. F. Richardson. Woodhead Publ. Limited, Cambridge, England.

Avi a ge n (2013). Ross 308 broiler: Nutrition specification. http://www.aviagen.com.

B a n k s K.M., T h o m p s o n K.L., R u s h J.K., A p p l e g a t e T.J. (2004). Effects of copper source on phosphorus retention in broiler chicks and laying hens. Poultry Sci., 83: 990-996.

B a o Y.M., Choct M., Ij i P.A., Bruerton K. (2007). Effect of organically complexed copper, iron, manganese, and zinc on broiler performance, mineral excretion, and accumulation in tissues. J. Appl. Poultry Res., 16: 448-455.

B r u n o L.D.G., L u qu e t t i B.C., F u r l a n b R.L., M a c a ri b M. (2007). Influence of early qualitative feed restriction and environmental temperature on long bone development of broiler chickens. J. Therm. Biol., 32: 349-354.

Chow dhury S.D., P a i k I.K., N a m kung H., Li m. H.S. (2004). Responses of broiler chickens to organic copper fed in the form of copper-methionine chelate. Anim. Feed Sci. Technol., 115: 281-293.

Cres p o R., S t o ve r S.M., Ta y 1 or K.T., C h in R.P., S h i v a p r a s a d H.L. (2000). Morphometric and mechanical properties of femora in young adult male turkeys with and without femoral fractures. Poultry Sci., 79 (4): 602-608.

Dibner J.J., R i chards J.D., Kitche 11 M.L., Quiroz M.A. (2007). Metabolic challenges and early bone development. J. Appl. Poultry Res., 16: 126-137.

Dobrzański Z., Korczyński M., Chojnacka K., Górecki H., Opaliński S. (2008). Influence of organic forms of copper, manganese and iron on bioaccumulation of these metals and zinc in laying hens. J. Elementol., 13 (2): 309-319.

Ferket P.R., Oviedo-Rondón E.O., Mente P.L., Bohórquez D.V., Santos A.A. Jr., Grimes J.L., Richards J.D., Dibner J.J., Felts V. (2009). Organic trace minerals and 25-hydroxycholecalciferol affect performance characteristics, leg abnormalities, and biomechanical properties of leg bones of turkeys. Poultry Sci., 88 (1): 118-131.

Ferretti J.L., Ca pozza R.F., Monde lo N., Montuori E., Z a n chetta J.R. (1993 a). Determination of femur structural properties by geometric and material variables as a function of body weight in rats. Evidence of sexual dimorphism. Bone, 14: 256-270.

F erretti J.L., C a p o z za R.F., Mond e lo N., M o n t u ori E., Z a n c he t t a J.R. (1993 b). Interrelationships between densitometric, geometric and mechanical properties of rat femora: inferences concerning mechanical regulation of bone modeling. J. Bone Miner. Res., 8: 1389-1395. 
F u c h s B., D u r o s o y S., G u ze k J. (2008). Effect of dietary Zn, Fe, Mn and Cu level and source on the productive, biochemical and physiological indices in lactating sows and their offspring. Zesz. Nauk. UP Wrocław, LVII, 567: 39-56.

Fuchs B., Kubizna J., Szuba-Trznadel A. (2009). Feeding of fattening pigs with the concentrate mixtures containing mineral and/or organic forms of $\mathrm{Cu}, \mathrm{Zn}, \mathrm{Mn}$ and Fe. Zesz. Nauk. UP Wrocław, LIX, 575: 87-100.

Gahrke M. (1997). Copper and manganese in the pathogenesis of bone diseases of animals. (in Polish). Med. Weter., 53 (11): 644-646.

Juli a n R. (2005). Production and growth related disorders and other metabolic diseases of poultry A review. Vet. J., 169: 350-369.

$\mathrm{K}$ w i e c i eń M. (2012). The effect of level and form of $\mathrm{Cu}$ and $\mathrm{Fe}$ in feed on performance and some metabolic indices of broiler chickens (in Polish). Rozpr. Nauk., UP Lublin, 359.

Kw i e c i eń M., Makarski B., Z a d u ra A., G a las D. (2005). The effect of adding copper lysine chelate on mineral composition and strength of tibia in turkeys (in Polish). Acta Sci. Pol. Zootech., 4 (2): $77-84$.

L e e s o n S. (2005). Trace mineral requirements of poultry - validity of the NRC recommendations. In: Re-defining mineral nutrition, Taylon-Pickard J.A., Tucker L.A. (eds). Nottigham University Press, pp. 107-117.

Mikulski D., Jankowski J., Zduńczyk Z., Wróblewska M., Mikulska M. (2009). Copper balance, bone mineralization and the growth performance of turkeys fed diet with two types of Cu supplements. J. Anim. Feed Sci., 18: 677-688.

Nollet L., Huyghebaert G., S pring P. (2008). Effect of different levels of dietary organic (bioplex) trace minerals on live performance of broiler chickens by growth phases. J. Appl. Poultry Res., 17: 109-115.

O vi e d o-R on dón E.O., F e r k e t P.R., H a ve n s te in G.B. (2006). Nutritional factors that affect leg problems in broilers and turkeys. Avian Poultry Biol. Rev., 17: 89-103.

R in a 1 d i A.C. (2000). Meeting report - copper research at the top. Biometals, 13: 9-13.

Wa ng Z., C e r r a te S., C o to C., Ya n F., W a l d r o u p P.W. (2007). Evaluation of Mintrex® copper as a source of copper in broiler diets. Int. J. Poultry Sci., 6 (5): 308-313.

Yan F., Waldroup P.W. (2006). Evaluation of Mintrex ${ }^{\circledR}$ manganese as a source of manganese for young broilers. Int. J. Poultry Sci., 5: 708-713.

Žili c S.M., B o ž o v i c I.N., S a v i c S., Š o b a j i c S. (2006). Heat processing of soybean kernel and its effect on lysine availability and protein solubility. Central Eur. J. Biol., 1 (4): 572-583.

Accepted for printing $21 \times 2013$ 